\title{
14
}

\section{The determinants of economic growth}

\section{Evidence from a panel of Chinese provinces}

\author{
Yanrui Wu
}

A recent resurgence of interest in economic growth has led to blossoming literature. ${ }^{1}$ Among the many approaches proposed, cross-country growth regressions have been widely applied to examine the role of various structural and policy indicators in economic growth. The findings in this large and growing literature often conflict and are yet to be sorted out. For example, Levine and Renelt (1992) carried out a sensitivity analysis of the determinants of the average annual growth rate of GDP per capita for a sample of 101 countries during the period 1960-89. According to their extreme bounds analysis, among many, only three variables (investment, international trade and initial income) are found to possess a fairly robust predictive power. Recently, Sala-i-Martin (1997) presented a more optimistic study which shows that a substantial number of variables are strongly related to growth. This finding is supported by Ley and Steel (1999).

One of the common features of the existing studies is their reliance on cross-section statistics. The main drawback associated with cross-country analyses is the presence of heterogeneity in data aggregation, economic structure and institutional framework among the countries considered. ${ }^{2}$ By focusing on a panel of Chinese provinces, this study may overcome the problems associated with heterogeneity in the existing literature and hence shed further light on the determinants of economic growth. China has undertaken two decades of economic reform and has achieved impressive growth. This study presents a timely assessment of China's economic performance over the past two decades. The next section describes the analytical framework and data issues. The 


\section{Dilemmas of China's Growth in the Twenty-First Century}

estimation results and analysis of the empirical findings are then presented. This is followed by an investigation of the robustness of the empirical results, with summary remarks presented in the final section.

\section{Analytical and data issues}

In the growth literature, a set of variables have been identified as being related to growth. ${ }^{3}$ The standard analytical framework is based on the following growth regression

$$
Y=\alpha X+\beta Z+\varepsilon
$$

where $Y$ is the average annual growth rate of GDP per capita, $X$ a set of variables or the so-called conditioning variables which are always included in the regression, and $\mathrm{Z}$ is a subset of variables, chosen from a pool of variables, which are assumed or identified to be important explanatory variables to growth. The choice of X-variables is based on either past empirical studies or economic theory. For example, Levine and Renelt (1992) selected the initial income, the initial secondary school enrolment rate, the average annual rate of population growth and the investment share of GDP as the X-variables. Salai-Martin (1997) chose the level of income, life expectancy and primary school enrolment rate in the initial year by assuming that these variables were good $a$ priori.

As this chapter focuses on a single country, the number of variables to be considered is relatively small. For instance, the political and institutional factors are not relevant in the case of a single country. As a result, this study investigates the influence of several key economic and policy indicators, such as physical capital stock, human capital, economic reform, infrastructure, the initial income, openness, labour productivity and foreign capital. Some stylised facts about these variables are detailed in the following sections. It is noted that Equation 14.1 implies causality from $\mathrm{X}$ and $\mathrm{Z}$ to $\mathrm{Y}$. This causal relationship should be tested. However this is beyond the scope of this study.

To capture the impact of foreign investment in China, capital stock is divided into domestic and foreign components. The Chinese government agencies have only published information on capital formation or the incremental capital which was available for all regions over the period 1952-97. As a result, the value of capital stock is estimated according to the following formula

$$
\mathrm{K}(\mathrm{t})=\Delta \mathrm{K}(\mathrm{t})+(1-\delta) \mathrm{K}(\mathrm{t}-1)
$$

where $\mathrm{K}(\mathrm{t})$ is the capital stock at time $\mathrm{t}$ for each region, $\delta$ is the rate of depreciation, and $\Delta \mathrm{K}(\mathrm{t})$ is the incremental capital at time t. $\Delta \mathrm{K}(\mathrm{t})$ is available for the period 1952-97 for all regions. The data series for $\Delta K(t)$ are backcasted to the year 1900. Accordingly, Equation 14.2 is expanded to

$$
\mathrm{K}(\mathrm{t})=\Sigma_{0}^{t-1901}(1-\delta)^{k} \Delta \mathrm{K}(\mathrm{t}-\mathrm{k})+(1-\delta)^{\mathrm{t}-1990} \mathrm{~K}(1900)
$$




\section{The determinants of economic growth}

Equation 14.3 implies that, given the value of capital stock in 1900 and an appropriate rate of depreciation, a capital stock series for each region can be derived. It is assumed that the rate of depreciation is four per cent and $\mathrm{K}$ (1900) equals zero. ${ }^{4}$ In addition, in the empirical analyses, capital stock and GDP are deflated by region-specific price indexes and expressed in 1990 constant prices.

Capital stock derived according to Equation 14.3 covers capital accumulation from both domestic and foreign investment. The value of domestic capital stock is the total value of capital stock net of the value of foreign capital stock. The latter is derived by applying a formula similar to Equation 14.3, with the initial year being 1981. China started receiving foreign capital in 1979. At the beginning, foreign direct investment (FDI) was small in scale and concentrated mainly in two southern provinces, Guangdong and Fujian. It slowly spread to other regions in the early 1980s. As a result of this development process, FDI figures by region are only available for the period 1982-97. To estimate foreign capital stock series for the regions, it is assumed that foreign capital was zero in 1981 and that the rate of depreciation is four per cent. ${ }^{5}$

Summary statistics of the estimated capital stock and other variables are reported in Table 14.1. The western and central regions have lagged behind coastal China. Their relatively slow economic growth matches their poor performance in many other areas, such as capital formation, foreign investment, openness, infrastructure development and human capital. This relationship should be captured by the growth regressions to be conducted in the following sections.

\section{Determinants of China's regional growth}

The empirical analysis begins with a baseline model which is employed to investigate the impact of physical capital accumulation and the initial income on regional growth. For the purposes of comparison, the empirical analyses focus on two periods: 1982-90 and 1991-97. The point of division is largely dictated by the availability of statistics. For example, many Chinese regions began receiving FDI in 1982, and population censuses were conducted in 1982 and 1990 , respectively. ${ }^{6}$ In addition, it is interesting to compare regional growth in the 1980s and $1990 \mathrm{~s}$.

\section{Capital accumulation and initial conditions}

Capital accumulation has often played a key role in economic growth (Young 1995). The average growth rate of capital stock is used in the estimations in this chapter. It is expected to be positively correlated with the rate of economic growth. The initial income is regarded as an important factor underlying 


\section{Dilemmas of China's Growth in the Twenty-First Century}

growth. ${ }^{7}$ It is argued that less developed economies may be able to take the advantage of backwardness and hence enjoy faster growth (Abramovitz 1986). The initial income variable in the empirical models takes the value of GDP per capita in the first year of the time period considered, and its coefficient is expected to have a negative sign. Equation 14.1 is applied to cross-section data of twenty-eight Chinese provinces (Table 14.2). The results from the baseline model (Model 1) are reported in column 2. The estimates of all coefficients have the appropriate sign and are statistically significant at the various levels shown.

As expected, the growth of physical capital stock (domestic) has made a significant contribution to economic growth over the periods considered. The initial level of income is found to be negatively related to economic growth. This relationship is significant at a given level of confidence. Thus, it may be concluded that there is evidence of conditional convergence among the Chinese regions over the past two decades. The rate of convergence is about 1.5 per cent per annum according to the baseline regressions. The coefficients of the two regional dummies have shown that the western regions grew relatively fast in the 1980s but lagged behind both the coastal and central regions in the 1990s. Thus, the estimated convergence as indicated by the sign of the initial income took place mainly within the regions. This finding is consistent with observations from regional disparity studies (Wu 2000).

Other factors such as infrastructure, labour productivity conditions, foreign capital, economic reform, openness and human capital have also played important roles in China's growth over time. However, these variables cannot enter the regressions simultaneously due to the existence of multicollinearity. For example, the coefficient of correlation between the variables representing infrastructure and economic reform and that between foreign capital and openness are relatively high (Table 14.3). As a result, various optional models are estimated.

\section{Infrastructure and labour productivity}

The level of infrastructure development can be proxied by several indicators, such as the length of roads and number of telephones. ${ }^{8}$ However, the use of the length of roads is likely to be biased against regions where rail is the dominant means of transportation. As a result, this study focuses on the number of telephones. Due to the fact that the large and relatively more developed regions always have more telephones, the growth rate of the number of telephones per head is used to reflect the change in infrastructure among the regions. The use of growth rate rather than level is also consistent with the case of other variables. It is clear from Table 14.1 that the regions led by Guangdong and Fujian have achieved substantial growth in infrastructure during 1982-97. 
The determinants of economic growth

\section{Table 14.1 Summary statistics of selécted variables}

\begin{tabular}{|c|c|c|c|c|c|c|c|c|c|}
\hline Regions & $\mathrm{Y}$ & GDP & K & PRO & INF & FK & REF & HK & OPEN \\
\hline \multicolumn{10}{|c|}{ Coastal regions } \\
\hline $\begin{array}{l}\text { Beijing } \\
\text { Tianjin } \\
\text { Hebei } \\
\text { Liaoning } \\
\text { Shanghai } \\
\text { Jiangsu } \\
\text { Zhejiang } \\
\text { Fujian } \\
\text { Shandong } \\
\text { Guangdong } \\
\text { Guangxi } \\
\text { Sub-mean }\end{array}$ & $\begin{array}{r}1087 \\
741 \\
325 \\
569 \\
1307 \\
441 \\
477 \\
385 \\
399 \\
531 \\
228 \\
590\end{array}$ & $\begin{array}{r}10.5 \\
9.6 \\
12.0 \\
9.7 \\
10.0 \\
13.5 \\
13.8 \\
14.2 \\
12.7 \\
14.5 \\
10.5 \\
11.9\end{array}$ & $\begin{array}{r}13.0 \\
9.8 \\
10.2 \\
9.3 \\
12.7 \\
12.4 \\
13.4 \\
11.2 \\
11.2 \\
9.9 \\
7.9 \\
11.0\end{array}$ & $\begin{array}{l}17.3 \\
17.4 \\
19.1 \\
17.9 \\
16.3 \\
20.5 \\
20.7 \\
22.8 \\
19.9 \\
21.8 \\
18.1 \\
19.3\end{array}$ & $\begin{array}{l}15.1 \\
20.5 \\
18.9 \\
18.2 \\
20.1 \\
23.8 \\
25.4 \\
27.8 \\
21.3 \\
29.8 \\
20.9 \\
22.0\end{array}$ & $\begin{array}{r}3.1 \\
3.3 \\
0.7 \\
2.0 \\
3.9 \\
2.6 \\
1.3 \\
8.6 \\
1.7 \\
11.0 \\
2.2 \\
3.7\end{array}$ & $\begin{array}{l}50.6 \\
77.6 \\
76.8 \\
68.6 \\
70.8 \\
82.3 \\
90.6 \\
88.8 \\
74.8 \\
87.3 \\
72.1 \\
76.4\end{array}$ & $\begin{array}{l}73.5 \\
61.1 \\
48.2 \\
58.7 \\
74.1 \\
47.9 \\
44.2 \\
39.0 \\
43.3 \\
47.7 \\
38.1 \\
52.4\end{array}$ & $\begin{array}{r}17.8 \\
25.8 \\
5.0 \\
11.8 \\
28.6 \\
10.2 \\
14.5 \\
24.3 \\
9.5 \\
96.4 \\
6.6 \\
20.1\end{array}$ \\
\hline \multicolumn{10}{|c|}{ Central regions } \\
\hline $\begin{array}{l}\text { Shanxi } \\
\text { Inner } \\
\text { Mongolia } \\
\text { Jilin } \\
\text { Heilongjiang } \\
\text { Anhui } \\
\text { Jiangxi } \\
\text { Henan } \\
\text { Hubei } \\
\text { Hunan } \\
\text { Sub-mean }\end{array}$ & $\begin{array}{l}302 \\
309 \\
353 \\
435 \\
218 \\
228 \\
226 \\
317 \\
255 \\
294\end{array}$ & $\begin{array}{r}10.0 \\
\\
10.4 \\
10.6 \\
7.8 \\
11.4 \\
11.0 \\
11.2 \\
11.1 \\
9.5 \\
10.3\end{array}$ & $\begin{array}{r}8.7 \\
10.1 \\
9.5 \\
9.2 \\
11.0 \\
8.9 \\
9.9 \\
9.7 \\
8.8 \\
9.5\end{array}$ & $\begin{array}{l}16.3 \\
\\
17.9 \\
18.4 \\
18.0 \\
17.4 \\
16.7 \\
18.2 \\
18.8 \\
16.9 \\
17.6\end{array}$ & $\begin{array}{l}13.6 \\
15.6 \\
19.0 \\
19.4 \\
21.2 \\
17.5 \\
19.7 \\
20.0 \\
20.2 \\
18.5\end{array}$ & $\begin{array}{l}0.2 \\
0.3 \\
0.9 \\
0.7 \\
0.7 \\
0.8 \\
0.5 \\
0.9 \\
0.9 \\
0.6\end{array}$ & $\begin{array}{l}68.0 \\
56.8 \\
40.5 \\
45.7 \\
80.2 \\
59.0 \\
72.4 \\
75.9 \\
75.2 \\
63.7\end{array}$ & $\begin{array}{l}53.8 \\
48.1 \\
55.1 \\
55.2 \\
41.5 \\
42.7 \\
49.5 \\
46.0 \\
45.0 \\
48.5\end{array}$ & $\begin{array}{r}6.6 \\
\\
4.7 \\
12.1 \\
16.9 \\
4.2 \\
4.7 \\
3.0 \\
5.1 \\
4.7 \\
6.9\end{array}$ \\
\hline \multicolumn{10}{|c|}{ Western regions } \\
\hline $\begin{array}{l}\text { Sichuan } \\
\text { Guizhou } \\
\text { Yunnan } \\
\text { Shaanxi } \\
\text { Gansu } \\
\text { Qinghai } \\
\text { Ningxia } \\
\text { Xinjiang } \\
\text { Sub-mean }\end{array}$ & $\begin{array}{l}240 \\
168 \\
259 \\
265 \\
226 \\
310 \\
284 \\
395 \\
268\end{array}$ & $\begin{array}{r}9.9 \\
9.4 \\
10.6 \\
10.2 \\
10.5 \\
8.0 \\
9.6 \\
11.1 \\
9.9\end{array}$ & $\begin{array}{r}8.6 \\
6.8 \\
8.8 \\
9.2 \\
6.6 \\
6.5 \\
7.7 \\
10.8 \\
8.1\end{array}$ & $\begin{array}{l}17.3 \\
14.1 \\
17.2 \\
16.8 \\
15.7 \\
15.5 \\
15.1 \\
19.8 \\
16.4\end{array}$ & $\begin{array}{l}17.8 \\
13.3 \\
18.5 \\
14.6 \\
15.9 \\
12.1 \\
18.5 \\
17.0 \\
16.0\end{array}$ & $\begin{array}{l}0.7 \\
0.4 \\
0.3 \\
1.2 \\
0.3 \\
- \\
0.1 \\
0.3 \\
0.4\end{array}$ & $\begin{array}{l}66.6 \\
44.0 \\
45.5 \\
48.8 \\
45.9 \\
27.2 \\
40.8 \\
24.7 \\
42.9\end{array}$ & $\begin{array}{l}38.1 \\
29.3 \\
28.5 \\
45.7 \\
37.4 \\
27.2 \\
42.8 \\
45.9 \\
36.9\end{array}$ & $\begin{array}{l}3.5 \\
3.0 \\
5.3 \\
5.4 \\
3.8 \\
3.6 \\
4.4 \\
5.0 \\
4.3\end{array}$ \\
\hline
\end{tabular}

Notes: Hainan Island and Tibet are excluded due to missing data.; $Y$ is 1991 GDP per capita in US dollars; GDP is the average growth rate of GDP (in per cent) for the period 1982-97; K is the average growth rate of domestic capital stock (in per cent) for the period 1982-97; PRO is the average growth rate of labour productivity (in per cent) for the period 1982-97; INF is the average growth rate of infrastructure (in per cent) for the period 1985-95; FK is the average share of foreign capital stock in total capital stock (in per cent) for the period 198297; REF is the output share of the non-state industrial sector in total industry (in per cent) in 1997; $\mathrm{HK}$ is the proportion of the population aged six and over with at least six years schooling in 1997; OPEN is the value of exports in GDP (in per cent) in 1993. 
Dilemmas of China's Growth in the Twenty-First Century




The determinants of economic growth

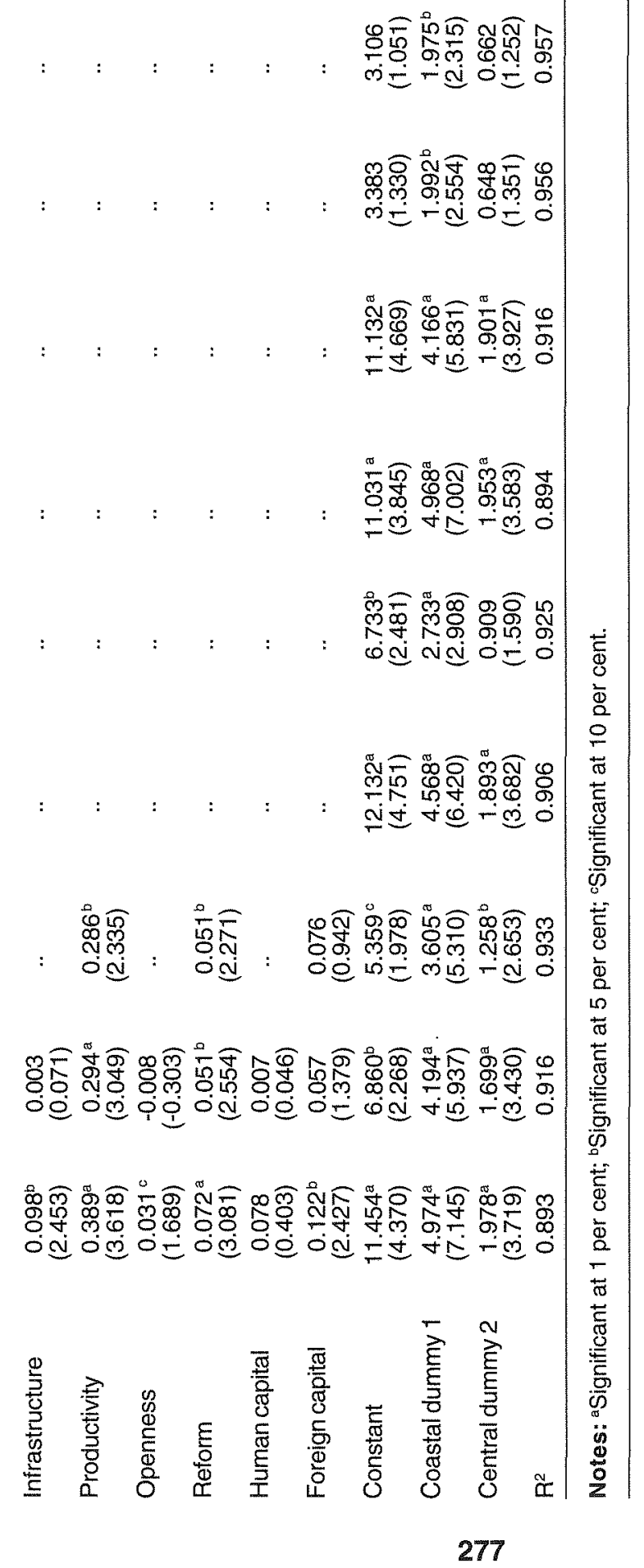




\section{Dilemmas of China's Growth in the Twenty-First Century}

This growth should have contributed positively to the regions' economic performance. The estimation results in Table 14.2 (Model 2) show that the coefficient of the infrastructure variable is positive and significant. Thus, infrastructure development is positively correlated with economic growth in Chinese regions.

Improvement in labour productivity is expected to make a positive contribution to growth. According to Table 14.2 (Model 3), the growth rate of labour productivity is positively related to growth during the two periods considered.

\section{Impact of economic reform and openness}

It is argued that economic reform has contributed significantly to China's growth over the past two decades. This claim is supported by empirical studies of the agricultural sector (McMillan et al. 1989; Lin 1992). In particular, one of the key reform initiatives was to open China to the world. As a result, China's economic take-off over the past two decades has been accompanied by rapid expansion of international trade. How have domestic reforms and external trade affected growth performance among the regions? To answer this question, reform and openness indicators are developed and incorporated into the growth regressions.

In the growth literature, the ratio of the total value of exports and imports (or the value of net exports) over GDP is employed as an indicator of openness. In the case of the Chinese provinces, it is found that the ratio of the total value of exports and imports over GDP is highly correlated with the ratio of the value of exports. ${ }^{9}$ Thus, either ratio can be used as the indicator of openness. In the final estimation, the ratio of the value of exports over GDP is used to represent openness. ${ }^{10}$ Not surprisingly, according to Table 14.1, Guangdong and Shanghai have the most open economies in China.

To reflect the progress of economic reform among the regions, the role and development of the non-state sector is examined. As its name suggests, the non-state sector includes all but the state sectors. Three indicators can be used to assess the development of the non-state sector: the shares of the non-state sector in urban employment, industrial output and total retail sales in the Chinese regions. In general, these three shares (which are available for various periods) have been rising over time, implying the deepening of China's economic reform (Figure 14.1). In the empirical models, after preliminary checking, the mean output shares of the non-state sector during 1985-90 and 1990-97 are used to proxy the degree of economic reform during the two periods. Coincidentally, the value of the output share is bound by the value of the employment and sales shares. The estimation results are reported in Table 14.2 (Models 4 and 5). The coefficients of both reform and openness variables 
Table 14.3 Selected coefficients of correlation, 1982-90

\begin{tabular}{llll}
\hline & Reform & Openness & Productivity \\
Domestic capital & $0.51(0.68)$ & $0.32(0.28)$ & $0.14(0.79)$ \\
Infrastructure & $0.58(0.72)$ & $0.91(0.26)$ & $0.50(0.76)$ \\
Foreign capital & $0.35(0.57)$ & $0.93(0.86)$ & $0.39(0.55)$ \\
\hline
\end{tabular}

Note: Numbers in parentheses are the coefficients for the period 1991-97.

have the correct signs and are significant, implying that China's reform and openness have contributed positively to economic growth over the past decades.

\section{The role of human capital}

The impact of human capital on China's growth has been rarely researched in the literature due to the paucity of data. The exceptions are Wei (1995), Moody and Wang (1997) and Démurger (2000). ${ }^{11}$ Wei used the number of scientific and technical personnel as a proxy of human capital. The other two authors employed school enrolment rates. These existing studies focus on one single cross-section only and hence ignore the growth of human capital over time. This study applies information from recent censuses to derive an estimate of human capital stock in the Chinese regions. China conducted population censuses in 1982 and 1990. A sample survey was also carried out in 1997. The census and survey data have now been published in various sources. This study uses two sets of data: the average level of schooling of the population and the level of education of the labour force. Ideally, the latter is an appropriate indicator of human capital but it is available for 1990 and 1997 only. However, statistics on the level of schooling of the population is available for 1982, 1990 and 1997. To justify the use of the 1982 census data, the two sets of data for 1990 and 1997 are compared. It is found that these data sets are highly correlated, with a coefficient of correlation greater than 0.99 . Due to this close relationship, the average level of education of the population is used to derive the level and growth rate of human capital stock among the regions.

The average rates of growth of human capital stock during 1982-90 and 1990-97 are employed in the regressions. It turns out that the coefficient of this variable is either negative or insignificant. Other authors have reported the same problem with the human capital stock variable (Benhabib and Spiegel 1994; Pritchett 1997). This may be due to measurement errors and technical constraints in deriving human capital stock data (Temple 1998). To overcome this problem, this study employs an alternative proxy for human capital; that is, the proportion of the population aged six and over with at least six years of schooling (the completion of primary school education). The average growth 


\section{Dilemmas of China's Growth in the Twenty-First Century}

\section{Figure 14.1 Selected shares of the non-state sector}

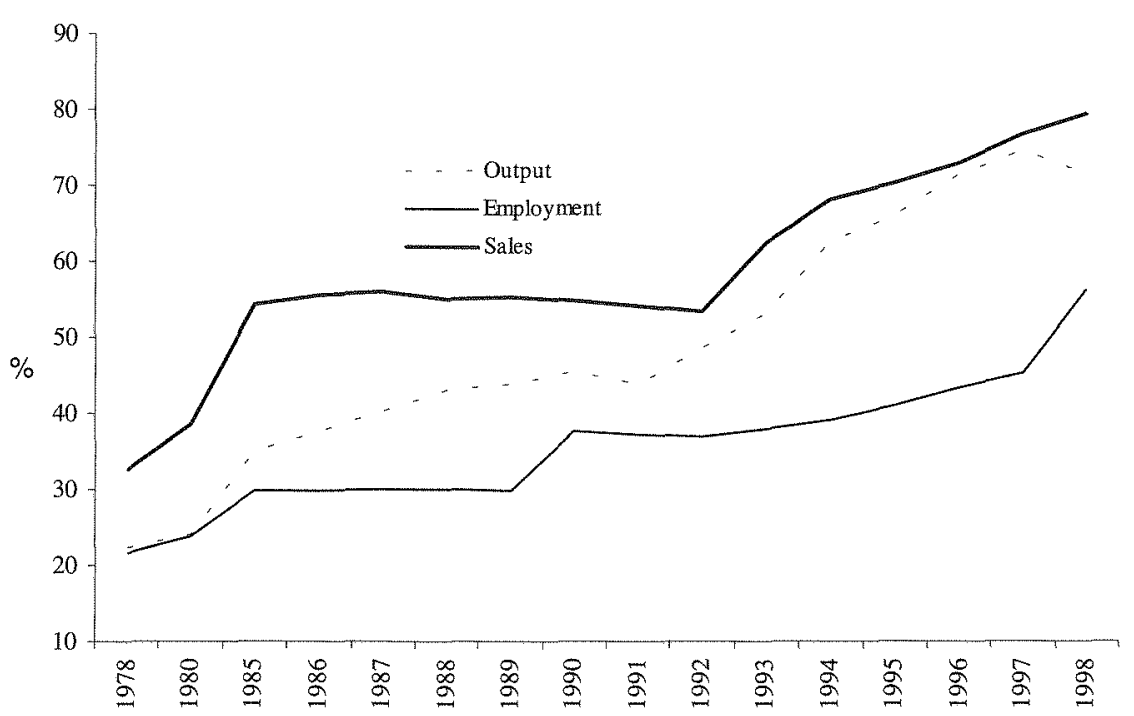

rate of this figure is used in the final estimation. According to Table 14.1 (and as expected) Shanghai and Beijing have the most educated population in China. It is also found that Anhui and Jiangxi-two central regions-have achieved the highest growth in human capital during 1982-97. It is found that the human capital variable has a positive coefficient which is significant during 1982-90 and insignificant during 1991-97 (Model 6 in Table 14.2). Thus, this result may imply that changes in human capital stock growth are positively correlated with economic growth in the Chinese regions. Obviously, this conclusion is subject to further qualification as better data and human capital theories become available in the future.

\section{FDI as an engine of growth}

According to new growth theory, FDI has been an important factor propelling economic growth. ${ }^{12}$ China's FDI increased significantly in the 1990s but the amount of investment varied considerably across the regions. In particular, some regions experienced hypergrowth in certain years due to the launch of a few large projects. As a result, regional growth rates of FDI vary significantly over time and the outliers in the data sample are problematic. To overcome this problem, the proportion of foreign stock in the total capital stock is employed in the empirical estimations. Foreign capital still plays a minor role 


\section{The determinants of economic growth}

in many regions, in particular in central and western China (Table 14.1). The final estimation results are reported in Table 14.2 (Model 7). According to this table, the contribution of FDI to China's growth in the 1980s and 1990s was significant.

\section{Results of pooled estimations}

The preceding sections examined the effect of various regional characteristics on economic growth. The objective of this section is to pool the data to investigate the joint impact of the variables on growth. One of the problems with the estimation of the pooled model is the existence of multicollinearity between the growth correlates (Table 14.3). For example, according to Table 14.3 , the variables for foreign capital and openness are highly correlated, and thus their appearance in the same growth equation would be problematic. Consequently, several models with different independent variables are estimated. The estimation results from two of those models are presented in the last two columns of Table 14.2. It is clear that those variables considered jointly explain about 70 and over 90 per cent of the growth in the 1980 s and 1990s, respectively.

\section{Sensitivity analyses}

Estimation results from the growth regressions are vulnerable to the presence of endogeneity and outliers. To check the robustness of the estimates, alternative methods of estimation have been attempted. This section presents the results from the least-trimmed square (LTS) estimation, the first-difference equations and the instrumental variable approach.

The LTS approach treats observations with high residuals as unrepresentative though the cut-off for a high residual is arbitrary. ${ }^{13}$ It is apparent that the exclusion of the outliers enhances the explanatory power of the growth regressions, particularly for the period 1982-90 (Table 14.4). In general, the LTS estimation results (for example, directions and magnitudes of the coefficients) are in conformity with the OLS findings in the preceding section (refer to Models 8 and 9 in Table 14.2 and Models 10-13 in Table 14.4). The existence of multicollinearity again prevents the inclusion of all explanatory variables in the same equation.

As capital (domestic, human and foreign) is an accumulated factor, the growth equation has been hampered by the problem of endogeneity. Benhabib and Spiegel (1994) provide evidence of upward biases on the coefficients of capital stock variables. To correct this problem, researchers have resorted to the difference equation and instrumental variable approaches. The estimation results from the difference equation approach are presented in the last two columns 


\begin{tabular}{|c|c|c|c|c|c|c|}
\hline \multirow{2}{*}{$\begin{array}{l}\text { Table 14.4 } \\
\text { Variables }\end{array}$} & \multicolumn{6}{|c|}{ Estimates of the LTS and difference equation approaches } \\
\hline & $\begin{array}{l}1982-90 \\
(10)\end{array}$ & (11) & $\begin{array}{l}1991-97 \\
(12)\end{array}$ & $(13)$ & $\begin{array}{l}\text { Differenc } \\
\text { (14) }\end{array}$ & $\begin{array}{l}\text { e equation } \\
\text { (15) }\end{array}$ \\
\hline Initial income & $\begin{array}{c}0.876 \\
(1.264)\end{array}$ & $\begin{array}{c}-0.760^{\mathrm{a}} \\
(-3.251)\end{array}$ & $\begin{array}{r}-0.790^{\circ} \\
(-2.724)\end{array}$ & $\begin{array}{r}-4.357^{a} \\
(-2.674)\end{array}$ & $\begin{array}{r}-4.697^{a} \\
(-2.752)\end{array}$ &. \\
\hline Domestic capital & $\begin{array}{r}0.168^{c} \\
(2.013)\end{array}$ & $\begin{array}{c}-0.038 \\
(-0.196)\end{array}$ & $\begin{array}{r}0.273^{a} \\
(2.738)\end{array}$ & $\begin{array}{r}0.269^{b} \\
(2.284)\end{array}$ & $\begin{array}{r}0.215^{\circ} \\
(1.738)\end{array}$ & $\begin{array}{r}0.233^{\circ} \\
(1.914)\end{array}$ \\
\hline Infrastructure & $\begin{array}{c}0.010 \\
(0.093)\end{array}$ & $\begin{array}{c}-0.028 \\
(-0.732)\end{array}$ & $\begin{array}{r}0.086^{a} \\
(2.577)\end{array}$ & $\begin{array}{r}0.098^{a} \\
(3.005)\end{array}$ & .. & .. \\
\hline Productivity & $\begin{array}{r}0.226^{\mathrm{a}} \\
(3.580)\end{array}$ & $\begin{array}{r}0.225^{\mathrm{a}} \\
(3.217)\end{array}$ & $\begin{array}{c}0.331^{\mathrm{a}} \\
(4.071)\end{array}$ & $\begin{array}{r}0.368^{\mathrm{a}} \\
(3.275)\end{array}$ & $\begin{array}{r}0.231^{\mathrm{a}} \\
(3.840)\end{array}$ & $\begin{array}{r}0.245^{\mathrm{a}} \\
(4.230)\end{array}$ \\
\hline \multirow[t]{2}{*}{ Foreign capital } & $0.393^{b}$ & 0.903 & $0.039^{a}$ & 0.076 & $0.132^{b}$ & $0.155^{\mathrm{b}}$ \\
\hline & $(2.430)$ & $(1.423)$ & (1.198) & $(1.223)$ & $(2.187)$ & $(2.433)$ \\
\hline Openness & $\begin{array}{c}-0.047 \\
(-0.821)\end{array}$ & $\begin{array}{c}-0.013 \\
(-0.627)\end{array}$ &.. & .. & .. & .. \\
\hline Reform & $\begin{array}{c}0.048^{\circ} \\
(1.939)\end{array}$ & $\begin{array}{r}0.079^{b} \\
(2.210)\end{array}$ & $\begin{array}{r}0.066^{a} \\
(3.944)\end{array}$ & $\begin{array}{r}0.072^{\mathrm{a}} \\
(3.886)\end{array}$ & $\begin{array}{c}-0.014 \\
(-0.335)\end{array}$ & .. \\
\hline Human capital & $\begin{array}{c}0.379 \\
(1.259)\end{array}$ & $\begin{array}{c}0.490 \\
(1.400)\end{array}$ & $\begin{array}{c}-0.033 \\
(-0.253)\end{array}$ & $\begin{array}{c}-0.213 \\
(-1.482)\end{array}$ &.. & .. \\
\hline Constant & $\begin{array}{c}1.510 \\
(1.173)\end{array}$ & $\begin{array}{c}-2.757 \\
(-0.760)\end{array}$ & $\begin{array}{c}2.267 \\
(1.120)\end{array}$ & $\begin{array}{c}2.514 \\
(1.101)\end{array}$ & $\begin{array}{c}-0.256 \\
(-0.188)\end{array}$ & $\begin{array}{c}-0.406 \\
(-0.248)\end{array}$ \\
\hline Coastal dummy1 & $\begin{array}{r}-2.060^{\mathrm{a}} \\
(-2.751)\end{array}$ & $\begin{array}{r}-2.526^{b} \\
(-2.764)\end{array}$ & $\begin{array}{r}1.542^{\mathrm{b}} \\
(2.447)\end{array}$ & $\begin{array}{r}1.394^{c} \\
(2.058)\end{array}$ & $\begin{array}{r}4.355^{\mathrm{a}} \\
(7.095)\end{array}$ & $\begin{array}{r}4.563^{\mathrm{a}} \\
(7.268)\end{array}$ \\
\hline Central dummy2 & $\begin{array}{r}-1.431^{\mathrm{a}} \\
(-3.588)\end{array}$ & $\begin{array}{r}-1.518^{\mathrm{a}} \\
(-3.516)\end{array}$ & $\begin{array}{c}0.196 \\
(0.466)\end{array}$ & $\begin{array}{c}0.156 \\
(0.348)\end{array}$ & $\begin{array}{r}2.395^{\mathrm{a}} \\
(5.025)\end{array}$ & $\begin{array}{r}2.559^{\mathrm{a}} \\
(4.925)\end{array}$ \\
\hline$R^{2}$ & 0.862 & 0.878 & 0.977 & 0.979 & 0.907 & 0.915 \\
\hline
\end{tabular}

Notes: aSignificant at 1 per cent; "Significant at 5 per cent; 'Significant at 10 per cent; Jilin, Heilongjiang, Gansu and Qinghai are excluded from the LTS regressions for the period 198290, as are Jilin, Jiangxi and Sichuan for the period 1991-97; The difference equations are estimated by an instrumental variable approach. The instrumental variables include all regressors in the equations and their lagged values.

(Models 14 and 15) of Table 14.4. The results support the claim of biased estimates from the OLS regressions; for example, the coefficients of domestic capital are biased upwards. Finally, the instrumental variable approach is often applied to account for the problem of endogeneity (Barro 1997). The estimation results (presented in Table 14.5) are consistent with the OLS estimation outcomes presented in the last two columns of Table 14.2.

\section{Conclusion}

Cross-country studies on economic growth have been criticised for overlooking heterogeneity among world economies. In contrast, studies focusing on a single 


\section{The determinants of economic growth}

\begin{tabular}{|c|c|c|c|c|c|c|}
\hline Table 14.5 & Estimates & of instrur & nental ve & lable mo & dels & \\
\hline Variables & $\begin{array}{l}1982-90 \\
(16)\end{array}$ & (17) & (18) & $\begin{array}{l}1991-97 \\
(19)\end{array}$ & $(20)$ & (21) \\
\hline Initial income & .. & $\begin{array}{c}0.058 \\
(0.113)\end{array}$ & $\begin{array}{c}0.444 \\
(0.713)\end{array}$ & $\begin{array}{r}-0.836^{\mathrm{a}} \\
(-3.376)\end{array}$ & $\begin{array}{c}-0.817^{a} \\
(-3.104)\end{array}$ & $\begin{array}{r}-0.776^{a} \\
(-2.676)\end{array}$ \\
\hline Domestic capital & .. & $\begin{array}{c}0.107 \\
(0.683)\end{array}$ & $\begin{array}{c}0.023 \\
(0.135)\end{array}$ & $\begin{array}{r}0.337^{a} \\
(3.252)\end{array}$ & $\begin{array}{r}0.336^{a} \\
(3.059)\end{array}$ & $\begin{array}{r}0.333^{\mathrm{a}} \\
(2.997)\end{array}$ \\
\hline Infrastructure & .. & $\begin{array}{c}0.067 \\
(0.584)\end{array}$ & .. & $\begin{array}{c}0.001 \\
(0.030)\end{array}$ & .. & .. \\
\hline Productivity & $\begin{array}{r}0.224^{\mathrm{a}} \\
(3.227)\end{array}$ & $\begin{array}{r}0.211^{\mathrm{a}} \\
(2.978)\end{array}$ & $\begin{array}{r}0.207^{\mathrm{a}} \\
(2.824)\end{array}$ & $\begin{array}{r}0.292^{\mathrm{a}} \\
(3.582)\end{array}$ & $\begin{array}{r}0.289^{\mathrm{a}} \\
(3.535)\end{array}$ & $\begin{array}{r}0.285^{\mathrm{a}} \\
(2.994)\end{array}$ \\
\hline Openness & .. & $\begin{array}{c}-0.057 \\
(-1.111)\end{array}$ & .. & $\begin{array}{r}-0.008^{c} \\
(-0.377)\end{array}$ & .. & .. \\
\hline Reform & $\begin{array}{r}0.086^{\mathrm{a}} \\
(4.661)\end{array}$ & $\begin{array}{r}0.068^{b} \\
(2.052)\end{array}$ & $\begin{array}{r}0.081^{\mathrm{b}} \\
(2.338)\end{array}$ & $\begin{array}{r}0.051^{\mathrm{a}} \\
(3.023)\end{array}$ & $\begin{array}{r}0.050^{\mathrm{a}} \\
(3.005)\end{array}$ & $\begin{array}{r}0.051^{\mathrm{a}} \\
(2.927)\end{array}$ \\
\hline Human capital & .. & $\begin{array}{c}0.285 \\
(0.841)\end{array}$ & $\begin{array}{c}0.210 \\
(0.594)\end{array}$ & $\begin{array}{c}0.024 \\
(0.216)\end{array}$ & $\begin{array}{c}0.020 \\
(0.161)\end{array}$ & .. \\
\hline Foreign capital & $\begin{array}{r}0.362^{\circ} \\
(1.812)\end{array}$ & $\begin{array}{r}0.388^{\mathrm{c}} \\
(1.940)\end{array}$ & $\begin{array}{c}0.848 \\
(1.581)\end{array}$ & $\begin{array}{r}0.057^{c} \\
(1.631)\end{array}$ & $\begin{array}{c}0.055 \\
(1.558)\end{array}$ & $\begin{array}{c}0.075 \\
(1.192)\end{array}$ \\
\hline Constant & $\begin{array}{r}3.406^{\mathrm{a}} \\
(3.271)\end{array}$ & $\begin{array}{r}1.714^{c} \\
(0.535)\end{array}$ & $\begin{array}{c}-0.159 \\
(-0.044)\end{array}$ & $\begin{array}{c}3.366 \\
(1.566)\end{array}$ & $\begin{array}{c}3.257 \\
(1.453)\end{array}$ & $\begin{array}{c}3.078 \\
(1.337)\end{array}$ \\
\hline Coastal dummy 1 & $\begin{array}{r}-2.598^{a} \\
(-4.610)\end{array}$ & $\begin{array}{l}-2.295^{b} \\
(-2.460)\end{array}$ & $\begin{array}{l}-2.585^{\mathrm{a}} \\
(-2.688)\end{array}$ & $\begin{array}{c}1.989^{\mathrm{a}} \\
(3.018)\end{array}$ & $\begin{array}{r}2.003^{\mathrm{a}} \\
(3.034)\end{array}$ & $\begin{array}{r}1.976^{\mathrm{a}} \\
(2.972)\end{array}$ \\
\hline Central dummy2 & $\begin{array}{r}-1.496^{\mathrm{a}} \\
(-3.563)\end{array}$ & $\begin{array}{r}-1.481^{a} \\
(-3.310)\end{array}$ & $\begin{array}{c}-1.454^{\mathrm{a}} \\
(-3.221)\end{array}$ & $\begin{array}{c}0.649 \\
(1.602)\end{array}$ & $\begin{array}{c}0.648 \\
(1.595)\end{array}$ & $\begin{array}{c}0.658 \\
(1.597)\end{array}$ \\
\hline$R^{2}$ & 0.695 & 0.711 & 0.723 & 0.956 & 0.956 & 0.957 \\
\hline
\end{tabular}

Notes: aSignificant at 1 per cent; ${ }^{b}$ Significant at 5 per cent; 'significant at 10 per cent; The instrumental variables include all regressors and their initial values.

country may suffer less from this problem. In this chapter, for the first time, several regression techniques are applied to investigate the determinants of recent economic growth in China. This study therefore adds to the existing literature and contributes to the current debate on the sources of economic growth.

Given the available data, the focus of this study is the impact on economic growth of eight region-specific factors (capital formation, initial income, infrastructure, labour productivity, economic reform, openness, human capital and foreign investment). In general, it is found that the growth of physical capital, infrastructure, labour productivity, human capital and foreign investment is positively related to China's economic growth in the 1980s and 1990s. This study also confirms the popular perception that China's economic reform and openness have made positive contributions to recent economic 


\section{Dilemmas of China's Growth in the Twenty-First Century}

growth. Furthermore, initial income is found to have a negative impact on growth rates, implying conditional convergence among the Chinese regions. This trend of regional convergence was particularly strong in the 1980s. The findings also show that convergence has occurred mainly within the coastal, central and western regions. There is no evidence of the western and central provinces catching up with their affluent counterparts, the coastal provinces. Overall, the empirical estimates show that the eight factors together account for 70-90 per cent of China's growth over the past two decades.

Finally, alternative models are estimated to take account of endogeneity and outliers. The above findings remain unchanged according to the alternative regressions. However, the findings are still subject to further qualifications. One of those is the measurement of human capital which is constrained by both methodology and available statistics (see Sachs and Warner 1997). In addition, there is also scope for improvement in the measurement of economic reform and openness as more information becomes available over time.

\section{Acknowledgments}

The author acknowledges the Australian Research Council for financial support under the small grant scheme and Bill Scanlan, Yewliang Lee, Robin Wong and Wana Yang for excellent research assistance. Additional thanks must also go to Cao Yong and an anonymous referee for helpful comments on an early draft.

\section{Notes}

1 See for example, Barro (1991), Levine and Renelt (1992) and Sala-i-Martin (1997).

2 See Temple (1999) for a review.

3 According to Sala-i-Martin (1997), the existing literature has employed over sixty variables as the correlates of growth.

4 Capital stock series are also derived by assuming the percentage rates of depreciation of 4 , 7 and 10, respectively. Information on the value of depreciation, which is available for the $1980 \mathrm{~s}$ and $1990 \mathrm{~s}$, is then used to test whether the assumed rates are statistically significant. As a result, 4 per cent is accepted and hence used for the final estimation of capital stock series.

5 Guangdong and Fujian are two exceptions. FDI received by these two provinces before 1982 is incorporated into the final estimation.

6 Over the past 50 years, China has only conducted four population censuses; in 1957 , 1964, 1982 and 1990.

7 Sala-i-Martin (1997) surveyed around sixty variables and found that the initial income has been included in most empirical studies.

8 Canning (1998) presented a detailed study of estimating indicators for world stocks of infrastructure. 


\section{The determinants of economic growth}

9 The coefficient of correlation is 0.96 according to the statistics in 1993. Regional trade figures are available from 1993 onwards.

10 It should be pointed out that in the early stages of economic reform, export licences were granted to companies in the coastal regions only. Though this policy has been abandoned gradually, it certainly brings about biases in the measurement of regional openness.

11 In addition, Yang (1998) and Cheung and Kwan (1999) investigated the impact of human capital on foreign investment.

12 For a review of the literature, see De Mello (1997) and Wu (1999).

13 See Rousseeuw and Leroy (1987) for details about the LTS estimation. 